Research Article

\title{
A Comparative Study of Nomegestrol Acetate and a Combination of Ethinylestradiol and Levonorgestrel for Delaying Menstruation among Umrah Pilgrims
}

\author{
Suatu Studi Komparatif Mengenai Nomegestrol Asetat dengan \\ Kombinasi Etinilestradiol dan Levonorgestrel untuk \\ Menunda Haid pada Jamaah Umrah
}

\author{
Mirzah Tindar' ${ }^{1}$, Yusuf Effendi' ${ }^{1}$, Adenan Abadi ${ }^{1}$, Theodorus ${ }^{2}$ \\ ${ }^{1}$ Department of Obstetrics and Gynecology \\ ${ }^{2}$ Research and Public Health Unit \\ Faculty of Medicine Universitas Sriwijaya/ \\ Dr. Mohammad Hoesin Hospital \\ Palembang
}

\begin{abstract}
Objective: To compare the effectiveness efficacy of nomegestrol acetate with and combination of ethinylestradiol and levonorgestrel as a regimen for delaying menstruation in Umrah pilgrims in Palembang city.

Methods: This single-blind randomized controlled trial was conducted in Hajj and Umrah Guidance Group in Palembang city during December 2016 to January 2017. Population of this study was 30 women who meet the inclusion and exclusion criteria. Frequency and distribution of data was described in a table. Effectiveness and the side effects treatment between the two groups were analyzed with Chi Square test. Data was were analyzed using SPSS version 18.0.
\end{abstract}

Results: There were no differences in age, education, occupation, parity, body weight, height and contraceptive history between two both groups (all p values $>0.05$ ). Statistical analysis showed there was no difference in spotting between nomegestrol acetate $5 \mathrm{mg}$ or a combination of levonorgestrel $150 \mathrm{mcg}$ and $30 \mathrm{mcg}$ ethinylestradiol in Umrah pilgrims $(\mathrm{p}=1.000)$. Other side effects such as (dizziness, depression, breast tenderness, heavy limbs, nauseam and vomiting) between the two groups could not be analyzed because all subjects did not experience any other side effects.

Conclusion: There is no difference in effectiveness between nomegestrol acetate $5 \mathrm{mg}$ or combination of levonorgestrel 150 mcg and $30 \mathrm{mcg}$ ethinylestradiol as a regimen for delaying menses in Umrah pilgrims in Palembang city.

[Indones J Obstet Gynecol 2018; 6-1: 45-49]

Keywords: delay menstruation, ethinylestradiol, levonorgestrel, nomegestrol, side effects, spotting, umrah

\begin{abstract}
Abstrak
Tujuan: Mengetahui perbandingan efektivitas nomegestrol asetat dengan kombinasi etinilestradiol dan levonorgestrel sebagai regimen penunda haid pada jamaah umrah di Kota Palembang.

Metode: Uji klinis acak berpembanding secara buta tunggal dilakukan di Kelompok Bimbingan Ibadah Haji Dan Umrah di kota Palembang pada periode bulan Desember 2016 sampai Januari 2017. Populasi penelitian ini sebanyak 30 wanita yang memenuhi kriteria inklusi dan eksklusi. Frekuensi dan distribusi data dijelaskan dalam bentuk tabel. Efektivitas perlakuan dan efek samping perlakuan antar kedua kelompok dianalisa dengan Uji Chi Square. Analisis data menggunakan SPSS versi 18.0.

Hasil: Tidak terdapat perbedaan usia, pendidikan, pekerjaan, paritas, berat badan, tinggi badan dan riwayat kontrasepsi antara kedua kelompok. Tidak terdapat perbedaan efek samping spotting antara perlakuan nomegestrol asetat $5 \mathrm{mg}$ maupun kombinasi levonorgestrel $150 \mathrm{mcg}$ dan etinilestradiol $30 \mathrm{mcg}$ pada jamaah umrah $(p=1,000)$. Efek samping lain (pusing, depresi, nyeri payudara, tungkai berat, mual dan muntah) antara kedua kelompok tidak dapat dianalisis karena seluruh subjek tidak mengalami efek samping lain.

Kesimpulan: Tidak terdapat perbedaan efektivitas antara nomegestrol asetat $5 \mathrm{mg}$ maupun kombinasi levonorgestrel $150 \mathrm{mcg}$ dan etinilestradiol 30 mcg sebagai regimen penunda haid pada jamaah umrah di Kota Palembang.
\end{abstract}

[Maj Obstet Ginekol Indones 2018; 6-1: 45-49]

Kata kunci: efek samping, etinilestradiol, levonorgestrel, nomegestrol, penundaan haid, spotting

\section{INTRODUCTION}

Menstruation occurs periodically in all healthy women who have with healthy reproductive organs. Menstrual cycle is often a problem for women (for example, when running Hajj or Umrah) because Islamic law forbids women who are menstruating to do prayer. Hajj and Umrah is a prayer that is performed at a given time and requires a certain amount of time and cannot be implemented at the time of menstruation. During 
menstruation, there are some prayer that should not be done, including: thawaf, praying, reading Quran, fasting and having a moment of silence in mosque. ${ }^{1-3}$

Advancement in the field of hormonal therapy has allowed us to regulate time of menstruation as desired, either to advance or delay menstruation using hormonal preparations such as progesterone, combined oral contraceptive pill, and GnRH

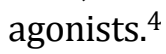

The mechanism of menstrual regulation using hormonal preparations is by suppressing production of endogenous estrogen and progesterone (ovarian) by providing a combination of exogenous hormones that suppress ovulation. Some regimens that can be provided to regulate menstrual cycle are progestin (progesterone or testosterone derivative), combination oral contraceptive (combination of estrogen and progestin), and gonadotropin releasing hormone agonist (GnRH). These preparations do not result in permanent infertility and menstrual cycle will back to normal after menstrual cycle regimen is stopped. ${ }^{2-5}$

Regulation of menstrual cycle, either to advance or delay menstruation was done to shift menstruation into some time before the pilgrimage begins or after the pilgrimage is completed. To reach that goal, we have to choose simple, rational, effective, efficient, and in expensive regiments. ${ }^{6}$

Westhoff $C$ et al. reported the use of nomegestrol acetate and $17 \beta$-estradiol, they found that $67.1 \%$ of women reported on time bleeding schedule and $85 \%$ reported on time bleeding until 12 cycles. In 2011 Australian State Health Department reported that $83.6 \%$ of women who use nomegestrol acetate did not report bleeding and spotting during the observation for 12 cycles. $^{7-9}$

In this study, we used acetate nomegestrol preparations (Lutenyl) and combination of ethinylestradiol and levonorgestrel (Microgynon). Both drugs are used because both are widely circulated, easy to obtain, have adequate contraceptive effect, and a relatively affordable price.

Providing reproductive health services, including regulating menstruation for woman who will do Hajj and Umrah is one of obstetrician resposibilities. Data regarding efficacy and side effects of regiments used to regulate menstruation during Umroh had not available. For that this study is aimed reason, we interested to compare effectiveness of nomegestrol acetate and combination of levonorgestrel and ethinylestradiol as a regimen for delaying menses in Umrah pilgrims in Palembang city.

\section{METHODS}

This was a single-blind randomized controlled trial. Study subjects are were blinded from regiments allocation. This study was conducted in Hajj and Umrah Guidance Group in Palembang from December 2016 until to 2017.

The population in this study were all Umrah pilgrims women in Hajj and Umrah Group Guidance $(\mathrm{KBIH} / \mathrm{U})$ in Palembang during 2016-2017.

Inclusion criteria was were Umrah pilgrims, were in the reproductive age (20-45 years), still having periods, not pregnant, not in infertility therapy, and willing to participate in this study proved by signing informed consent.

Exclusion criteria were previous history of removal of the uterus or both ovaries, having diseases in kidney, liver, or heart, history of embolism, postpartum <4 weeks, history of DVT (deep vein thrombosis), hypertension, migraine with aura, cervical cancer, endometrial cancer, breast cancer, taking drugs that interact with hormonal preparations, and refused to participate in this study.

Women who met the inclusion criteria were given a serial number then they were asked to sign informed consent. We did anamnesis history taking, physical examination and gave an explanation about this study to study subject. Subjects were given nomegestrol acetate $5 \mathrm{mg}$ (Lutenyl) 1 time a day orally or combination of levonorgestrel $150 \mathrm{mcg}$ and $30 \mathrm{mcg}$ ethinylestradiol (Microgynon) 1 time a day orally. Drugs taken on day 5 (maximum in day 14) of menstrual cycle every day until Umrah was completed. Subjects were given a bleeding and side effects control card and it must be filled during drugs comsumption.

The effectiveness and side effects of the treatment between two groups were analyzed using Chi Square. Data was were analyzed using SPSS version 18.0. Frequency and data distribution were described in table 5 . 


\section{RESULTS}

Demographic characteristics of study subjects are presented in Table 1. We did not find any differences in age, education, employment, weight and height, parity, marital status and history of contraception among group receiving $5 \mathrm{mg}$ of nomegestrol acetate and combination of levonorgestrel $150 \mathrm{mcg}$ and $30 \mathrm{mcg}$ ethinylestradiol. We can conclude that our study results were not influenced by demographic factors and those two groups was comparable.

From statistical analysis, we did not found significant difference in incidence of spotting (mid periode bleeding) between among groups who received nomegestrol acetate $5 \mathrm{mg}$ and combination of levonorgestrel $150 \mathrm{mcg}$ and 30 mcg ethinylestradiol $(\mathrm{p}=1.000)$ (Table 2).

All study subjects either in nomegestrol acetate $5 \mathrm{mg}$ group and combination of levonorgestrel 150 mcg and $30 \mathrm{mcg}$ ethinylestradiol did not reported other side effects (such as dizziness, depression, breast tenderness, heavy limbs, nausea and vomiting), for this reason we could not perform statistical analysis.

Table 1. Characteristics of Study Subjects

\begin{tabular}{|c|c|c|c|}
\hline \multirow{2}{*}{ Characteristics } & \multirow{2}{*}{$\begin{array}{l}\text { Study Groups } \\
\text { Nomegestrol } \\
\text { asetate } 5 \mathrm{mg}\end{array}$} & \multirow{2}{*}{$\begin{array}{c}\text { p-value } \\
\begin{array}{c}\text { Levonorgestrel } 150 \mathrm{mcg}+ \\
\text { Etinylestradiol } 30 \mathrm{mcg}\end{array}\end{array}$} & \\
\hline & & & \\
\hline Age (years), mean \pm SD & $33.13 \pm 9.67$ & $36.33 \pm 7.96$ & $0.372^{*}$ \\
\hline \multicolumn{4}{|l|}{ Education } \\
\hline SD & 0 & 0 & $0.183^{* *}$ \\
\hline SMP & 1 & 2 & \\
\hline SMA & 5 & 9 & \\
\hline University & 9 & 4 & \\
\hline \multicolumn{4}{|l|}{ Employment } \\
\hline Housewife & 8 & 11 & $0.405^{* *}$ \\
\hline Private company & 2 & 1 & \\
\hline Civil servant & 2 & 0 & \\
\hline Student & 3 & 2 & \\
\hline Midwife & 0 & 1 & \\
\hline \multicolumn{4}{|l|}{ Marital status } \\
\hline Married & 11 & 13 & $0.651^{* *}$ \\
\hline Not married & 4 & 2 & \\
\hline Weight $(\mathrm{kg})$, mean \pm SD & $56.8 \pm 8.00$ & $58.6 \pm 6.02$ & $0.277^{*}$ \\
\hline Height $(\mathrm{cm})$, mean \pm SD & $154.40 \pm 5.64$ & $154.13 \pm 4.21$ & $0.752^{*}$ \\
\hline Parity, mean \pm SD & $2.067 \pm 1.87$ & $2.533 \pm 1.55$ & $0.463^{* * *}$ \\
\hline \multicolumn{4}{|l|}{ Contraceptive } \\
\hline history & 10 & 8 & $0.719^{*}$ \\
\hline No contraception & 1 & 2 & \\
\hline Injectable & 3 & 2 & \\
\hline IUD & 1 & 2 & \\
\hline Pills & 0 & 1 & \\
\hline Implant & & & \\
\hline
\end{tabular}

*Mann Whitney, $-p=0.05$

${ }^{* *}$ Chi Square (Pearson, Fisher exact test), $p=0.05$

*** Independent T Test, $p=0.05$ 
Table 2. Comparison of Spotting after Study Intervention

\begin{tabular}{lccccc}
\hline \hline Characteristics & $\begin{array}{c}\text { Nomegestrol } \\
\text { acetate 5 mg }\end{array}$ & $\begin{array}{c}\text { Levonorgestrel 150 mcg + } \\
\text { Etinylestradiol 30 mcg }\end{array}$ & Total & $\mathbf{p}^{*}$ & \\
\hline Spotting $(+)$ & & 2 & 1 & 3 & 1.000 \\
Spotting $(-)$ & & 13 & 14 & 27 & 30 \\
Total & 15 & 15 & 15 & 30 \\
\hline \hline
\end{tabular}

*Fisher exact test, $p=0.05$

\section{DISCUSSION}

Menstruation is a natural process for all normal women and a sign of fertility. Normal menstrual cycle is about 28 days but can be forward or backward and ranged from 22 days to 35 days with an average volume of blood about $130 \mathrm{ml}$. Menstruation is often a problem for women who will do Hajj or Umrah because Islamic law forbids menstruating women to worship God. Solutions to address this problem is by regulating menstrual cycle, including forward or delay menstruation using hormonal preparations such as progesterone, combined oral contraceptive pill, and agonists GnRH. ${ }^{1-4}$

Preparations for menstrual regulation should be simple, rational, effective, efficient, and inexpensive. Delaying menstruation can be done using combined contraceptive pill (estrogen and progestin) or using progesterone only pills. In this study we used single dose of hormonal preparations (nomegestrol acetate $5 \mathrm{mg}$ under the brand mixes Lutenyl) and combinations dose (levonorgestrel $150 \mathrm{mcg}$ and $30 \mathrm{mcg}$ ethinylestradiol the trademark Microgynon). 6 ,7

Statistical analysis showed that there were no differences in age, education level, employment, marital status, weight, height, parity and contraceptive history between two groups so that both groups were comparable.

The most common side effects occurs after nomegestrol acetate administration are bleeding (spotting), amenorrhea, edema, allergic. But however, in this study, bleeding (spotting) only occurs by $13.3 \%$. Incidence of spotting in combination pill was quite low $(6.7 \%) .^{7-10}$

In this study we found only three subjects that experienced spotting, two from nomegestrol acetate $5 \mathrm{mg}$ group and 1 from combination of levonorgestrel $150 \mathrm{mcg}$ and $30 \mathrm{mcg}$ ethinylestradiol group. Statistic analysis showed that there was no difference in spotting between nomegestrol acetate $5 \mathrm{mg}$ group or combination of levonorgestrel $150 \mathrm{mcg}$ and $30 \mathrm{mcg}$ ethinylestradiol group. We did not found other adverse effects in both groups. From those results it can be concluded that nomegestrol acetate $5 \mathrm{mg}$ group and 1 from combination of levonorgestrel $150 \mathrm{mcg}$ and $30 \mathrm{mcg}$ ethinylestradiol have the same effectiveness as regimen to delay menstruation and has no adverse side effects.

Other side effects that often occur after nomegestrol acetate $5 \mathrm{mg}$ or combination of levonorgestrel $150 \mathrm{mcg}$ and $30 \mathrm{mcg}$ ethinylestradiol administration were nausea, abdominal pain, weight gain, headaches, distressed and breast tenderness. These side effects can occur in $\geq 1 \%$ of users, but in this study those side effects were not found. $8,11,12$

Nomegestrol acetate is a potent oral progestogens that have has a good tolerability profile and neutral metabolic characteristics. Nomegestrol acetate, or 19-nomegestrol acetate, is a hormonal contraceptive that is selective for receptor binding progesteron and have smaller power against other steroid receptors such as androgen receptor, estrogen, glucocorticoid and mineralocorticoid receptors. As a result, this hormone has no androgenic, estrogenic, glucocorticoid or mineralocorticoid effect. Nomegestrol acetate has been used to treat gynecological disorders (menstrual disorders, dysmenorrhea, and premenstrual syndrome) and as a component in hormone replacement therapy combined with estradiol to reduce symptoms of menopause. Nomegestrol acetate has a good effect on lipid profile, and has no bad effect on glucose metabolism. Nomegestrol acetate showed no proliferative activity in normal breast or women who have malignancy, and do not give a bad effect on bone formation. ${ }^{7-10}$ 
The combination of estradiol and levonorgestrel is commonly used as an oral contraceptive. Combination pill is effective to inhibit activity of hypothalamo-pituitary-ovarial axis. Menstruation delay can also achieve with combined contraceptive pill (estrogen and progestin). Use of combination hormone is usually more effective to suppress activity of hypothalamo-pituitary-ovarian axis than single hormone but have greater side effects. This was contrast with results of this study which shows that incidence of spotting or other adverse effects between single hormone or combination preparation was not different. ${ }^{11,12}$

\section{CONCLUSION}

There is no difference in effectiveness between nomegestrol acetate $5 \mathrm{mg}$ or combination of levonorgestrel $150 \mathrm{mcg}$ and $30 \mathrm{mcg}$ ethinylestradiol as a regimen for delaying menses menstruation in Umrah pilgrims in Palembang city.

\section{RECOMMENDATION}

Based on the study results, drugs choice should depend on the preferences of each woman.

\section{REFERENCES}

1. Astarto NW, Djuwantono D, Tjahyadi D. Menunda Haid dan Mengatasi Masalahnya ketika Beribadah Haji dan Umrah. Step by Step Penanganan Kelainan Endokrinologi reproduksi dan Fertilitas dalam Praktik sehari-hari. CV Sagung Seto. Jakarta. 2012: 5-20.

2. Dahlan S, Sarjana. Kontroversi Pil Tunda Haid Selama Haji. 2007. Available at: http://www.wordpress.com/2014.html

3. Rajuddin. Ibadah Haji dan Upaya Mengatur Siklus Haid. Majalah Ilmiah Ukhuwah, Universitas Al Wasliyah, Medan. 2009; 4(2): 169-79.

4. Baziad A. Penggunaan Progesteron dalam Pengobatan. Ilmu Kandungan. PT Bina Pustaka Sarwono Prawirohardjo. Jakarta. 2009: 648.

5. Caitlin WH, Ellen SR. Menstrual Manipulation: Options for Supressing The Cycle. Cleveland Clin J Med. 2010; 27: 44551.

6. Frankovich RJ, Lebrun CM. Menstrual Cycle, Contraception and Perfomance. Clin Sport Med. 2000; 19: 251-71.

7. Westhoff C Kaunitz AM, Korver T, Sommer W, et al. Efficacy, Safety, and Tolerability of a Monophasic Oral Contraceptive Containing Nomegestrol Acetate and 17 $\beta$-Estradiol. A Randomized Controlled Trial. Obstet Gynecol 2012; 119: 98999.

8. Department of Health and Ageing, Australian Government. Australian Public Assessment Report for Nomegestrol acetate/oestradiol. 2011: 1-101.

9. Conyngham RB. Noretisterone in menorrhagia. New Zealand Med J 64: 697-701.

10. Greenblat RB, Junck EC. Delay of menstruation with norethindrone, an orally given progestational compound. JAMA. 1958; 166(12): 1461-3.

11. Miller L, Hughes JP. Continous Combination on contraceptive pils to eliminate withdrawal bleeding. A randomized trial. Obstet Gynecol. 2003; 101: 653-66.

12. Sulak P, Kueh T, Ortiz M, Shull BL. Acceptance of altering the standard 21 day 17 day oral contraceptive regimen to delay menses and reduce hormone withdrawal symptoms. Am J Obstet Gynecol. 2002; 186: 1142-9. 